\title{
Latent introduction to the Netherlands of multiple antibiotic resistance including NDM-1 after hospitalisation in Egypt, August 2013
}

E Bathoorn (d.bathoorn@umcg.nl) ${ }^{1}$, A W Friedrich ${ }^{1}$, K Zhou ${ }^{1}$, J P Arends ${ }^{1}$, D M Borst ${ }^{1}$, H Grundmann ${ }^{1}$, J W Rossen ${ }^{1}$

1. Department of Medical Microbiology, University of Groningen, University Medical Center Groningen, Groningen, The Netherlands

Citation style for this article:

Bathoorn E, Friedrich AW, Zhou K, Arends JP, Borst DM, Grundmann H, Rossen JW. Latent introduction to the Netherlands of multiple antibiotic resistance including NDM-1 after hospitalisation in Egypt, August 2013. Euro Surveill. 2013;18(42): pii=20610. Available online: http://www.eurosurveillance.org/ViewArticle.

aspx?Articleld $=20610$

Article submitted on 11 October 2013 / published on 17 October 2013

We describe the introduction of various multi-drug resistant bacterial strains, including an NDM-1producing Klebsiella pneumoniae, through a traveller returning from Egypt, where they had been admitted to a private hospital. All family members of the patient were colonised with one or more extended-spectrum beta-lactamase producing strains. These findings emphasise the importance of adherence to isolation precautions for returning patients and suggest the need for inclusion of Enterobacteriaceae in admission screening.

We here report of a patient who had been hospitalised in Egypt for appendicitis in July 2013, and was colonised with various multiresistant Enterobacteriaceae including strains producing NDM-1, oxacillinase-48 (OXA-48) and extended spectrum beta-lactamase (ESBL). Explorative screening for multiresistant microorganisms among the patient's family members also yielded several ESBL-producing microorganisms. This report addresses the need for heightened awareness of patients and family members who have recently been exposed to healthcare environments in countries with high levels of antibiotic resistance.

Patients repatriated after hospitalisation abroad are a risk for introducing multiresistant microorganisms into hospitals in their home countries. In 2008, New Delhi metallo-beta-lactamase (NDM), which hydrolyses lastline carbapenem antibiotics, has been for the first time described in a Swedish patient returning from India [1]. Most reports on NDM are related to travellers returning from Pakistan and India. However, the global dispersal of NDM is of growing concern [2]. In the past two years, NDM-producing strains have been reported in patients returning from the African continent without obvious links to the Indian subcontinent $[3,4]$.

\section{Case description}

A Dutch patient in their 405 was admitted to our hospital for fever and abdominal pain. On admission, computed axial tomography showed a periappendicular abscess. Four days earlier, the patient had returned from holidays in Egypt with his spouse and two children. One week into their holidays (two weeks before presentation at our hospital) the patient had complained about right lower abdominal pain and was admitted to a private hospital in Egypt where $400 \mathrm{mg}$ ciprofloxacin twice a day and $500 \mathrm{mg}$ metronidazole three times a day were given intravenously for two weeks. The patient was discharged after 13 days without having undergone any surgical intervention, and subsequently returned to the Netherlands.

In our hospital, the abscess was drained and the patient was treated with piperacilin/tazobactam 4,500 $\mathrm{mg}$ three times a day intravenously for five days with good clinical response.

A perianal screening swab taken on admission grew Klebsiella pneumoniae, which was resistant to meropenem (minimum inhibitory concentration: $32 \mathrm{mg} / \mathrm{L}$ ). Molecular testing of the strain by PCR and sequencing of the $P C R$ product revealed that the strain harboured the gene encoding NDM-1. Molecular testing of faeces detected OXA-48, and culture of this sample grew Escherichia coli and $K$. pneumoniae positive for OXA-48.

We also screened the patient's spouse and children, who had been visiting the patient in the hospital in Egypt. Stool samples were obtained 14 days after admission of the index patient. The Table shows an overview of the screening results for multiresistant microorganisms of the family. The patient, his spouse and the youngest child carried ESBL-producing strains with CTX-M1. The older child carried two different ESBLproducing $E$. coli strains positive for CTX-M9. A gene encoding $K$. pneumoniae carbapenemase (KPC) was detected by molecular tests from faeces of the youngest child. The culture of this sample remained negative for carbapenemase-producing strains. Screening of contact patients on the ward where the index patient was treated did not reveal further dissemination of any resistant strains. 
TABLE

Carbapenemase and/or extended-spectrum beta-lactamaseproducing strains from samples of a family returning to the Netherlands from Egypt, August 2013

\begin{tabular}{|c|c|c|c|c|}
\hline $\begin{array}{l}\text { Strain/resistance } \\
\text { encoding genes }^{a}\end{array}$ & $\begin{array}{l}\text { Index } \\
\text { patient }\end{array}$ & Spouse & $\begin{array}{l}\text { Older } \\
\text { child }\end{array}$ & $\begin{array}{l}\text { Younger } \\
\text { child }\end{array}$ \\
\hline $\begin{array}{l}\text { Klebsiella pneumoniae/ } \\
\text { NDM1, CTX-M1, all }_{1} \\
\text { TEMs }^{\text {b }}\end{array}$ & + & & & \\
\hline $\begin{array}{l}\text { Escherichia coli/OXA- } \\
48 \text {, CTX-M1 }\end{array}$ & + & & & \\
\hline $\begin{array}{l}\text { K. pneumoniae/OXA- } \\
48 \text {, SHV }\end{array}$ & + & & & \\
\hline $\begin{array}{l}\text { E. coli/CTX-M1, all } \\
\text { TEMs }^{\mathrm{b}}\end{array}$ & + & & & \\
\hline $\begin{array}{l}\text { E. coli/CTX-M1, all } \\
\text { TEMs }{ }^{\text {b }} \text { except for } \\
\text { TEM } 104\end{array}$ & & & & + \\
\hline E. coli/CTX-M1 (no TEM) & + & + & & \\
\hline E. coli/CTX-M9 & & + &,$++^{c}$ & \\
\hline $\begin{array}{l}\text { Resistance genes } \\
\text { detected directly on } \\
\text { stool samples }^{\text {d }}\end{array}$ & & & & \\
\hline $0 \times A-48$ & + & & & \\
\hline KPC & & & & + \\
\hline
\end{tabular}

a Strains phenotypically non-susceptible to third generation cephalosporins and/or carbapenems were tested for resistance genes by microarray Checkpoint chip CT103 (Checkpoints, Wageningen, the Netherlands). Detected ESBL-encoding genes (TEM-104, TEM-164, TEM-238, SHV, CTX-M) and carbapenemaseencoding genes (KPC, NDM, OXA-48, VIM, IMP) are reported.

b 'All TEMs' refers to detection of TEM-104, TEM-164 and TEM-238.

Two CTX-M9 producing E. coli strains were found, which were phenotypically different and had distinct antimicrobial resistance patterns.

d Stool samples of all family members were tested for carbapenemase-encoding genes (KPC, OXA-48, VIM, NDM) by the microarrays Check-Direct CPE (Checkpoints, Wageningen, the Netherlands) and Hyplex Superbug ID (Amplex Biosystems $\mathrm{GmbH}$, Gießen Germany).

\section{Discussion}

High prevalence of ESBL-producing bacteria with rates of over $60 \%$ in Egyptian hospitals has been reported $[5,6]$. Also outbreaks involving OXA-48- and VIM-1 carbapenemase-producing strains have been described in the southern Mediterranean region including Egypt [7]. The occurrence of an NDM-1-producing Acinetobacter in Egypt has previously been reported, but so far no reports of NDM-1-producing Enterobacteriaceae could be found in the literature [8]. This is in contrast to other countries in the area such as Morocco and the United Arab Emirates where these bacteria have already been isolated [9-11].
Highly sensitive and rapid screening methods are the mainstay to prevent introduction of multiresistant microorganisms in hospitals in low prevalence countries by repatriated patients. Molecular tests that allow detection of carbapenemase-encoding genes directly from clinical samples are promising when used in addition to conventional culturing [12].

In the youngest child, we detected a KPC gene by two molecular testing methods directly from faeces, but we were not able to confirm these findings by culture. The bacterial load of the KPC- producing strain was probably too low to be cultured.

It is well recognised that repatriated patients are a risk for introducing multiresistant microorganisms. Family members attending patients hospitalised abroad may also be at risk of acquiring multiresistant bacteria, as our case illustrates. Although we cannot be sure that the family members picked up all strains in the hospital in Egypt, the diversity of multiresistant microorganisms including strains rarely found in the Netherlands makes this highly plausible. Neither can we rule out that the strains were acquired in Egypt outside the hospital, since travelling to African countries has been described as a risk factor for ESBL carriage [13].

Based on these findings, we recommend alertness and compliance with isolation precautions. Infection control guidelines may need to be expanded to include admission screening for resistant Enterobacteriaceae in low prevalent counties for a growing number of international travellers, including family members who have visited a patient abroad.

\section{Conflict of interest}

None declared.

Authors' contributions

EB collected the data and drafted the manuscript; AWF participated in the coordination and concept of the manuscript; KZ performed and analysed the molecular tests; JPA participated in the coordination and concept of the manuscript and helped with the draft of the manuscript; DB organised the sample collection and participated in the concept of the manuscript; HG coordinated and edited the manuscript; JWR supervised the molecular research and analysis. 


\section{References}

1. Yong D, Toleman MA, Giske CG, Cho HS, Sundman K, Lee K, et al. Characterization of a new metallo-beta-lactamase gene, bla(NDM-1), and a novel erythromycin esterase gene carried on a unique genetic structure in Klebsiella pneumoniae sequence type 14 from India. Antimicrob Agents Chemother. 2009;53(12):5046-54

http://dx.doi.org/10.1128/AAC.00774-09

PMid:19770275 PMCid:PMC2786356

2. Kumarasamy K, Kalyanasundaram A. Emergence of Klebsiella pneumoniae isolate co-producing NDM-1 with KPC-2 from India. J Antimicrob Chemother. 2012;67(1):243-4.

http://dx.doi.org/10.1093/jac/dkr431

PMid:21990048

3. Brink AJ, Coetzee J, Clay CG, Sithole S, Richards GA, Poirel L, et al. Emergence of New Delhi metallo-beta-lactamase (NDM-1) and Klebsiella pneumoniae carbapenemase (KPC-2) in South Africa. J Clin Microbiol. 2012;50(2):525-7. http://dx.doi.org/10.1128/JCM.05956-11 PMid:22116157 PMCid:PMC3264190

4. Poirel L, Benouda A, Hays C, Nordmann P. Emergence of NDM1-producing Klebsiella pneumoniae in Morocco. J Antimicrob Chemother. 2011;66(12):2781-3. http://dx.doi.org/10.1093/jac/dkr384 PMid:21930570

5. Mohamed Al-Agamy MH, El-Din Ashour MS, Wiegand I. First description of CTX-M beta-lactamase-producing clinical Escherichia coli isolates from Egypt. Int J Antimicrob Agents. 2006;27(6):545-8.

http://dx.doi.org/10.1016/j.ijantimicag.2006.01.007 PMid:16713187

6. Talaat M, Hafez S, Saied T, Elfeky R, El-Shoubary W, Pimentel $G$. Surveillance of catheter-associated urinary tract infection in 4 intensive care units at Alexandria university hospitals in Egypt. Am J Infect Control. 2010;38(3):222-8. http://dx.doi.org/10.1016/j.ajic.2009.06.011 PMid:19837480

7. Poirel L, Abdelaziz MO, Bernabeu S, Nordmann P. Occurrence of OXA-48 and VIM-1 carbapenemase-producing Enterobacteriaceae in Egypt. Int J Antimicrob Agents. 2013;41(1):90-1. http://dx.doi.org/10.1016/j.ijantimicag.2012.08.015 PMid:23040010

8. Hrabak J, Stolbova M, Studentova V, Fridrichova M, Chudackova E, Zemlickova H. NDM-1 producing Acinetobacter baumannii isolated from a patient repatriated to the Czech Republic from Egypt, July 2011. Euro Surveill. 2012;17(7):pii=20085. Available from: http://www. eurosurveillance.org/ViewArticle.aspx?Articleld $=20085$ PMid:22370014

9. Poirel L, Benouda A, Hays C, Nordmann P. Emergence of NDM1-producing Klebsiella pneumoniae in Morocco. J Antimicrob Chemother. 2011;66(12):2781-3. http://dx.doi.org/10.1093/jac/dkr384 PMid:21930570

10. Sonnevend A, Al Baloushi A, Ghazawi A, Hashmey R, Girgis S, Hamadeh MB, et al. Emergence and spread of NDM-1 produce Enterobacteriaceae with contribution of Inc $X_{3}$ plasmids in the United Arab Emirates. J Med Microbiol. 2013;62(Pt 7):1044-50 http://dx.doi.org/10.1099/jmm.0.059014-0 PMid:23579399

11. Dash N, Panigrahi D, Al Zarouni M, Darwish D, Ghazawi A, Sonnevend A, et al. High Incidence of New Delhi MetalloBeta-Lactamase Producing Klebsiella pneumoniae Isolates in Sharjah, United Arab Emirates. Microb Drug Resist. 2013 Aug 30. Epub ahead of print. http://dx.doi.org/10.1089/mdr.2013.0040 PMid:23992285

12. Miriagou V, Cornaglia G, Edelstein M, Galani I, Giske CG, Gniadkowski M, et al. Acquired carbapenemases in Gram negative bacterial pathogens: detection and surveillance issues. Clin Microbiol Infect. 2010;16(2):112-22. http://dx.doi.org/10.1111/j.1469-0691.2009.03116.x PMid:20085605

13. Peirano G, Laupland KB, Gregson DB, Pitout JD. Colonization of returning travelers with CTX-M-producing Escherichia coli. Travel Med. 2011;18(5):299-303.

http://dx.doi.org/10.1111/j.1708-8305.2011.00548.x

PMid:21896092 